\title{
Frames of Corruption in Zimbabwe: A Critical Analysis of Online Public Responses to the Zimdef Corruption Scandal of 2016
}

\author{
Rodwell Makombe \\ Mpitseng Tladi
}

\begin{abstract}
The advent of the new media, particularly social networks and discussion forums, has challenged the dominance of mainstream media by creating a platform for ordinary citizens to frame news objects and set the agenda of public discourse. This article critically analyses popular responses to corruption among the political elite in Zimbabwe with a specific focus on the Zimdef corruption scandal of 2016. The study is a sequel to a paper published in the Journal of African Media Studies (2018, vol.10. no.1) which focused on how Zimbabwean newspapers framed the Zimdef corruption scandal. This article is different in that it focuses on how newspaper readers (as opposed to journalists) re-presented or re-framed the corruption scandal in their reading of the Zimdef story. While the first paper established that newspapers framed Jonathan Moyo (and by extension ZANU PF) as corrupt and morally bankrupt, this study examines ordinary people's attitude towards corruption among public officials by interrogating their reading of the Zimdef narrative. We collected data from discussion forums of six Zimbabwean newspapers that ran the Zimdef corruption story, namely The Chronicle, NewsDay, The Independent, The Herald, The Standard and NewsZimbabwe.com. Results of the analysis show that ordinary Zimbabweans do not necessarily subscribe to or consume frames promoted by newspapers. Some respondents, particularly those who belong to minority groups, saw corruption as a way of distributing national resources to the politically and economically marginalised.
\end{abstract}


Keywords: Jonathan Moyo, newspapers, frame, corruption scandal, media, newsreaders

\section{Introduction}

In their theorisation of the agenda setting and news-framing role of the media, scholars of media studies such as McCombs (2014) and Entman (1993) have argued that ordinary citizens consume (and in their opinions are shaped by) media frames and agendas of mainstream media. In recent years, this view has become a site of contestation both theoretically and practically. While scholars such as Meraz (2011), Borah (2011), and Cacciatore et al. (2016) have started to question the primacy of mainstream media in framing news and setting the agenda of public discourse, practical developments, such as Donald Trump's election to the US presidency, show that citizens no longer rely on mainstream media to define what is important in their lives. By voting Donald Trump to the US Presidency and by continuing to support his policies in spite of the negative publicity that he receives from mainstream media, ordinary Americans demonstrate their refusal to conform to mainstream media frames and agendas. Similarly, the demonization of Jacob Zuma in South Africa's mainstream media did not deter ordinary citizens from supporting his candidature in 2009 and his subsequent controversial radical economic transformation policies. In fact, even after his removal, some sections of South African society continued to oppose mainstream media frames by celebrating him as a symbol of radical economic transformation.

These developments highlight that mainstream media no longer has control over what issues people think about and how they think about those issues. The emergence of a growing number of alternative media, which allow citizens to 'collect and share information without having to resort to journalists or other professionals', has further threatened mainstream media's 'monolithic ability to demarcate widespread public perception' (Aruguete 2017:36). The study argues that the emergence of the new media has democratised the agenda setting and news framing roles of the media. Ordinary citizens now have the ability to not only produce information and set their own agendas, but also to oppose the news frames and agendas of mainstream media.

The study critically analyses newsreaders' responses to the Zimdef corruption scandal against the backdrop of a mainstream media that framed 
Jonathan Moyo ${ }^{1}$ as an immoral, self-serving and corrupt politician. In 2016, Zimbabwe's major newspapers namely The Herald, Newszimbabwe.com, The Standard, The Independent, The Chronicle and NewsDay published different versions of the Zimdef corruption scandal. The first paper in this sequel focused on how newspapers framed the story in an attempt to influence public opinion. This study, however, critically examines popular responses to the different versions of the Zimdef corruption scandal published by Zimbabwean newspapers in October/November 2016. The question is how ordinary Zimbabweans read, interpreted and re-framed the Zimdef corruption scandal. Most online newspapers provide discussion forums where ordinary citizens engage with headline stories. We analyse selected public posts on each newspaper's discussion forum in an attempt to determine how newsreaders (as opposed to journalists) re-framed the story, portrayed by newspapers as a criminal offence.

The Zimdef corruption scandal relates to a story in which the then Minister of Tertiary Education and Technology, Professor Jonathan Moyo, allegedly siphoned public funds from the Zimbabwe Manpower Development Fund (Zimdef) to finance personal and party-political interests. Following this scandal, most newspapers in Zimbabwe published stories that portrayed Moyo and his compatriots as morally bankrupt criminals who deserved a prison sentence. The researchers in this study considered the question whether it is possible to decipher a Zimbabwean national attitude towards corruption through analysing popular responses to corruption cases that involve the political elite? The point of departure in this analysis is the assertion that mainstream media such as newspapers no longer have total control over public discourse because citizens have access to digital platforms where they do not only consume but also produce information.

Two theoretical frameworks, namely framing and agenda setting underpin this study. Broadly speaking, a frame is 'a prism for demarcating space' (Makombe 2018: 74). The concept, 'framing' refers to the selection, packaging and highlighting of content or information so that it appears as the only truth about a particular subject. A frame is therefore the sum total of carefully selected pieces of information. A frame 'tries to organize people's perceptions by urging them to attend what is within it and ignore what is

\footnotetext{
${ }^{1}$ Jonathan Moyo is former Minister of Tertiary Education and Technology who was involved in the Zimdef corruption scandal.
} 
outside of it' (Ardèvol-Abreu 2015: 428). The way a picture looks has a bearing on the way viewers see and interpret it. Similarly, the way newsorganisations present news affects the way their readers/viewers interpret and understand events. This implies that while news-producers frame or package news in a certain way to serve a particular agenda, readers/viewers also read and view news from a particular perspective (and not necessarily from the perspective imposed by the media). Gamson (1996) defines a frame as a central organizing idea for making sense of relevant events and suggesting an issue. Goffman (1974) recognises a frame as both a social framework and a mental schema that allows users to organise experiences. Kinder and Sanders (1990) note that frames are embedded both in political discourse and internal structures of the mind. Journalists and/or news organisations subscribe to particular cultural/political frameworks that influence the way they frame news. Similarly, the public reads/views news through the lenses of their own cultural/political frames. For Gamson and Modigliani (1989) news frames are 'interpretative packages' that give meaning to an issue. Frames are not only interested in providing information on a particular matter but also making moral judgements through evaluating causal agents and their effects.

Semetko and Valkenburg (2000) proposed five frames that the media often deploys in reporting news, namely, the attribution of responsibility, conflict, human interest, economic consequences and morality. 'Attribution of responsibility' is concerned with finding the cause and solution to a problem. 'Conflict frames' focus on conflict or misunderstanding between individuals and groups, for example, who has done what to who and what is likely to happen. The 'human-interest frame' focuses on how things that happen affect people, for example, how corruption among the political elite affects the lives of ordinary citizens. The 'economic consequences frame' emphasises the possible economic consequences of events, for example, how the impasse between the United States and Iran is likely to affect the markets. Finally, yet importantly, the 'morality frame' evaluates and portrays events in terms of right and wrong, for example, is it right to bomb a mosque or a church? While most of the literature seems to associate framing and news frames with journalists and media organisations, this study argues that readers also frame and repackage news in ways that can sway public discourse.

In a study on media representations of the Egyptian Arab Spring of 2012, Hamdy and Gomaa (2012:207) found that social media postings by ordinary citizens 'depended on human interest frames that emphasized the 
suffering and resiliency of ordinary Egyptians in the face of a repressive regime'. While opposition media framed the demonstrators as revolutionaries, government media portrayed them as 'disruptive forces' and 'unemployed thugs, foreign conspirators, and delinquent and violent youth who did not have the national good at heart'. What is evident in these frames is that in times of crisis, political sympathy often influences and shapes the media's news frames. In a study on media frames of school shootings in the US, Park et al. (2012: 477) found that the media accentuates the race of perpetrators if they 'happen to belong to a group that is already marginalised or viewed as inherently criminal, such as immigrants'. Oftentimes, media frames of school shootings that involve white males ignore race while those that involve Black and immigrant males emphasise race.

The foregoing discussion shows that the media does not only seek to provide information but also promotes an agenda. Agenda setting theory asserts that the media does not only influence what citizens think but also how they think about particular issues. The media sets the agenda by telling people 'what to think about based on issues being covered more frequently or more prominently' (Cacciatore 2016: 11). Agenda setting theory's position that traditional media has power to influence both what the public thinks about an issue (issue agenda setting) and how the public thinks about it (attribute agenda setting) (Meraz 2011: 108), has become contestable in a network society where 'citizens can bypass traditional media to engage with other, like-minded citizens' (Moy, Tewksbury and Rinke (2016:5). Although the media is usually successful in setting the agenda for complex issues such as climate change, it is not as successful on issues that resonate with the personal experience of individuals.

This article makes use of this framework to analyse ordinary citizens' responses to the Zimdef corruption scandal as reflected through comments posted by readers on discussion forums of selected newspapers. Idid and Elawad (2015) employed this framework to study the influence of new media agendas on traditional news media in Sudan. In a study that employed agenda setting to analyse the interface between traditional and new media, Natalia Aruguete (2017) found that new media often follows stories published in mainstream media although they provide a platform for individuals to extend and interrogate the agendas of mainstream media. Meraz (2011: 100) intimates that 'unlike the prior age of media, in this age of networked media, amateurs as opposed to professionals power the new information economy, which is 
founded on creating, sharing, and republishing media on the web'

Bode et al. (2010: 9) also argue that mainstream media no longer has monopoly over agenda setting. In some cases, new media platforms such as YouTube 'act as fire starters among the media, giving editors enough reason to investigate and report the given subject matter as news and draw the public's attention to it'. What is evident in the foregoing is that 'the contemporary news environment allows the public, or the people formerly known as the audience to exert substantial influence on agenda-building and news-framing processes' (Moy, Tewksbury and Rinke 2016: 14). Bode et al. (2010) investigated how mainstream and social media influenced public discourse through the way they reported California's Proposition 8 , a notorious statute that outlawed same sex marriage. The study showed that social media interrogated the statute for a much longer period than mainstream media thus allowing 'individuals an opportunity to help drive - and at times lead - public discourse on socially relevant and politically important issues' (Bode et al. 2010: 26). Social media and online discussions forums are platforms that ordinary people appropriate to frame their own news, set their own agendas and oppose or affirm the news frames and agendas of mainstream media.

\section{Corruption through Public Lenses: Newsreaders' Framing of the Zimdef Scandal}

In October 2016, news headlines in Zimbabwean media carried a corruption scandal, which accused former Cabinet Minister, Professor Jonathan Moyo, of misappropriating funds from Zimdef, a public fund which mainly consists of a $1 \%$ levy that registered companies in Zimbabwe contribute towards skills development. The purpose of the fund is to finance the development of a critical and highly skilled work force, mainly through providing funding to tertiary institutions. The Minister, as trustee of the fund, has the prerogative, in consultation with the National Manpower Advisory Council (Namaco), to approve the release of funds based on his discretion (Makombe 2018: 76). Most newspapers that published the corruption scandal claimed that Jonathan Moyo and his Deputy, Godfrey Gandawa, had abused their power and privileges by using Zimdef funds to serve their own interests and those of their political party, ZANU PF. The purpose of this article is to assess public readings and representations of corruption in Zimbabwe by analysing public texts that reflect on the Zimdef corruption scandal, how ordinary people frame corrupt- 
tion in Zimbabwe, and whether they embrace the news frames and agendas of mainstream media. We collected data from discussion forums of six selected newspapers. Readers posted many comments in response to the selected stories. However, the researchers purposively selected three comments from each discussion forum guided by research questions, which sought to, firstly, examine how ordinary citizens read and interpreted the corruption scandal; and secondly, interrogate ordinary people's attitude towards corruption in Zimbabwe.

\section{Methodology}

This study analysed how ordinary citizens re-framed the Zimdef corruption scandal through their reading of versions of the Zimdef corruption story published in six Zimbabwean newspapers namely, The Chronicle, NewsDay, The Independent, The Herald, The Standard and NewsZimbabwe.com. We considered popular representations of the scandal worth investigating because they are likely to provide a different perspective while at the same time providing us with an opportunity to analyse public attitudes towards corruption in Zimbabwe. The six newspapers captured divergent framings of the scandal and accommodated different political inclinations given that newspapers in Zimbabwe tend to represent issues from different political perspectives. We sampled stories through an online search using the key words 'Zimdef scandal' and 'Professor Jonathan Moyo'. The search generated 28900 results, which included stories published by both national and international media organisations. Only stories published in the selected six newspapers between 7 October and 12 November were included because this is the time when the corruption scandal was in the hands of Zimbabwe's judicial system and the AntiCorruption Commission. Stories published after the official conclusion of the case (dismissal) were not included in the analysis. Moreover, only those stories that revealed new information were included in the analysis. The selected stories consisted of those that, either subscribed to Semetko and Valkenburg's (2000) media frames, or introduced new ways of framing the story.

\section{Data Presentation and Analysis}

Although the media plays an important role in shaping public opinion, findings in this study suggest that readers/viewers do not always accept the news frames 
and agendas set by mainstream media. Newspapers in Zimbabwe framed the Zimdef corruption scandal as an act of criminality that deserved prosecution. Moyo and his accomplices were depicted as insensitive and greedy politicians who pretended to serve the people when they were serving their own selfish ends. However, ordinary citizens who read the corruption stories did not necessarily agree with the way the newspapers framed Jonathan Moyo. While some readers condemned corrupt behaviour among public officials, others applauded Jonathan Moyo's actions as the only way to share national resources in Zimbabwe. Most of the readers framed the scandal in line with Semetko and Valdenburg's (2000) five media frames namely attribution of responsibility, human interest, economic consequences, conflict and morality. However, some readers framed the scandal as a political circus and a reflection of President Mugabe's failure to control his own party and the wayward behaviour of his ministers.

When the Zimdef scandal surfaced in 2016, Zimbabwe's AntiCorruption Commission (ZACC) investigated the matter and made recommendations to the President. During interviews with ZACC officials and on public platforms such as Facebook and Twitter, Jonathan Moyo denied any wrongdoing and defended himself. He argued that he had used the money to sponsor political activities of the ruling party such as the One Million Man march $^{2}$. The latter was a purely partisan exercise meant to show that President Mugabe still had the support of most Zimbabweans. Moyo's admission that he had used the money to sponsor party activities came across as an admission of guilt because under normal circumstances, public funds cannot support activities of a political party. Readers of the story 'Prof Moyo case shocking details' (Ncube 2016), published by The Standard on 14 November 2016 saw this argument as a desperate attempt by Moyo to justify abuse of public funds. A reader by the name Dokezh gave a sarcastic comment:

It's as if using state funds for a million-man march is justifiable kkkkkkk. What a shameless bunch this party of boot lickers is! Can't pay your civil service but can sponsor a million man march

2 This march was organized by ZANU-PF on 25 March 2016 to demonstrate support for President Mugabe against the backdrop of increasing opposition from within and without Zimbabwe. 
Dokezh frames the corruption scandal as a reflection of the political chaos that reigned within ZANU PF in the last years of Mugabe's rule. Unlike The Standard, which focused on unearthing the details of Moyo's corruption, Dokezh is interested in the humorous dimensions of the story. He categorises ZANU PF politicians, including Moyo, as 'a shameless bunch' of 'bootlickers' probably because of their failure at the time to challenge Mugabe's political hegemony. For Dokezh, Moyo's claim that he had used Zimdef funds to sponsor ZANU PF political activities is a joke because sponsoring partisan activities cannot justify abusing state funds. The repeated 'kkkkkk' at the end of the first sentence shows that Dokezh is actually laughing at what he perceives as a weak argument presented by Moyo. In his theorisation of the post colony, Mbembe (2001) argues that the grotesque and the obscene punctuate the relationship between the ruled and the rulers. Dokezh's comment turns the scandal and officialdom into objects of ridicule. His comment shows that he/she is not interested in challenging the status quo but laughing at the absurdity of officialdom. As Mbembe (2001) argues, the relationship between Dokezh (the ruled) and the political elite (the rulers) is that of 'illicit cohabitation' rather than confrontation. Similarly, another reader by the name Trevor characterises the Zimdef scandal as 'the joke of the century':

This is the joke if the century. Surely of all the people you appoint Chombo to investigate a case of corruption? ... Zvinopedza power.

Trevor's comment ridicules the committee that President Mugabe set up to investigate allegations of corruption within the Anti-Corruption Commission. He views the committee as an attempt by then President Mugabe to sweep Moyo's case under the carpet. One of the members of the committee, Ignatius Chombo, the then Minister of Home Affairs, was implicated in various corruption scandals in Zimbabwe. For Trevor, appointing Chombo to investigate a case of corruption is tantamount to asking a criminal to investigate another criminal. The appointment of a 'committee of criminals' to investigate corruption was evidence that President Mugabe was not serious about eradicating corruption. 'Zvinopedza power' literally means this decision is disheartening and makes Trevor lose hope in the future of Zimbabwe. When The Standard published the story, 'Prof Moyo case shocking details', it sought to influence public opinion by revealing the details of the corruption scandal. However, Trevor and Dokezh re-frame the scandal as a political circus that 
would not result in the prosecution of wrong doers.

The story 'Prof Moyo in 270k corruption' storm' published by The Chronicle (Anon 2016) attracted numerous comments from different readers. The Chronicle is a daily newspaper published in Bulawayo, the capital city of Matabeleland. A cursory look at the comments shows that most of the readers are probably Ndebele-speaking readers who felt aggrieved about economic marginalisation in their region. The comments project Moyo as a champion of regional economic empowerment. One reader identified as Sikhulu believes that Moyo's misappropriation of funds was not a criminal act at all because 'money was redirected to other pressing national issues (transport problems)'.

Moyo knows the problems of his people and many children were not going to school because of transport and he saw where he can cut in order to make this provision. That's excellent economics by professor.

Although Sikhulu is sympathetic to Moyo's quasi-redistributive economics, there is a hint of irony in his comments. He probably appreciates Moyo's attempt to address challenges in his home province, however, he also mocks his modus operandi. As far as this reader is concerned, there is nothing morally wrong with Moyo's behaviour. The Chronicle story relied on ZACC's statistical breakdown of how Moyo spent the money he siphoned from Zimdef. In view of these figures, Sikhulu jokingly suggests that Moyo spent the money in a transparent manner because everyone now knows how he spent it. The irony is that Moyo only revealed how he spent the money after an investigation by the Anti-Corruption Commission. For Sikhulu 'transparency' has more to do with 'how' rather than 'why' Moyo spent the money. However, the last statement 'that's excellent economics professor' is more of a parody on the professor's idea of economics than praise.

Similarly, a reader by the name GodlawayoOmnyama criticised The Chronicle for focusing on small scandals while ignoring serious ones committed by 'big fish' in Zimbabwe's sea of corruption. The name 'GodlawayoOmnyama' is a sentimental invocation of Ndebele royal pride epitomised by the Ndebele kingdom of the $19^{\text {th }}$ century. GodlawayoOmnyama supports Moyo while condemning the Shona people (the ruling ethnic group in Zimbabwe) whom he perceives as more corrupt than the Ndebeles people. This reader sees The Chronicle story as biased because it demonises Moyo while absolving other corrupt politicians within the ruling party. According to this 
reader, Moyo used the money 'to develop his constituency' and he does not deserve to be persecuted because 'all other top dogs' thieving ways have not been reported'.

GodlawayoOmnyama sympathises with Moyo whom he perceives as a victim of ethnic politics. The comment draws from ethnocentric discourses that construct Zimbabwe as a country of two conflicting ethnic groups, the Ndebeles and the Shonas. This reader holds all Shona speakers responsible for mismanaging the country's economy and neglecting people in Matebeleland. GodlawayoOmnyama probably knows that Moyo is guilty. However, his concern is that the The Chronicle decided to vilify Moyo while other corrupt politicians walk free. He gives the example of Mugabe who allegedly 'made his unqualified Nigerian son in law the COO of Air Zim'. Mugabe's son in law, Simba Chikore, became COO at Air Zimbabwe amidst public outcry from citizens who felt that he was not qualified for the job and that his appointment was irregular and corrupt. It is not clear why this reader calls Chikore a 'Nigerian son in law'; however, this resonates with rumours that claim that Mugabe himself was not Zimbabwean.

Anotherr reader, Royal Mthwakazi, defends Moyo and frames him as a scapegoat of the internal politics of ZANU PF. The name 'Royal Mthwakazi' embodies the ethnic pride of the Ndebele and their aspiration for selfdetermination. Royal Mthwakazi's comment resonates with what Semetko Valkensburg (2000) characterise as the conflict frame. It brings a new twist to the scandal by suggesting that Moyo is serving his people with diligence. Royal Mthwakazi does not only refuse to frame Moyo as a corrupt politician but also challenges The Chronicle's definition of corruption. Moyo's behaviour (which The Chronicle calls corruption) seeks to right a wrong in Zimbabwean society - the continued marginalisation of people in Matebeleland.

Royal Mthwakazi locates himself within the imagined borders of the 'Mthwakazi' nation. In recent years, the name 'Mthwakazi' has been associated with a group of Ndebele nationalists who derive inspiration from the pre-colonial Ndebele kingdom. The political party, Mthwakazi Liberation Front (MLF), believes that the Ndebeles will only be free if they seceded and established their own nation. Moyo's people, according to this reader, are royal Ndebeles who, allegedly, remain marginalised in a Shona dominated nation. As far as this reader is concerned, Moyo works for the Mthwakazi nation and not for Zimbabwe which is a construct of corrupt Shona speaking people.

The story 'Jonathan Moyo's many corruption faces' published by 
NewsZimbabwe.com (Anon 2016) also attracted several comments from various readers. Moe Syzlack did not accept NewZimbabwe.com's conceptualisation of Moyo as the hydra of Zimbabwean politics. He acknowledges that 'Musorobhangu is a thief' but he believes that Zimbabwe had other more corrupt politicians such as 'airhead Mboko'. Syzlack's use of derogatory language expresses his frustration with the political elite in Zimbabwe. 'Musorobhangu' is Jonathan Moyo's nickname derived from the shape of his head. In fact, Moyo got the nickname when President Mugabe described his head as 'hard like a mutamba fruit' (musoro wake wakaoma sedamba $)^{3}$. Syzlack believes that Zimbabweans should focus on the 'big fish' such as former Vice President, Phelekezela Mphoko or 'airhead Mboko', who upon his appointment to the Vice Presidency stayed in a hotel for several months citing security reasons and in spite of the country's economic challenges. The name 'Mboko' which is a corruption of 'Mphoko' is a curse word that refers to a person of decadent morals or literally a fool. The reference to Mphoko's corrupt behaviour, (refusing to vacate a 5-star hotel and setting his cronies free from police stations), suggests that Syzlack does not see corruption as an individual problem but a societal cancer in Zimbabwe. It seems corruption has become synonymous with the ruling party and Moyo's case is merely a tip of the iceberg. SekaQinisela wase Nkayi also interprets Moyo's case from an ethnocentric/regional perspective. He uses derogatory language such as 'tshonas' to refer to Shonas and misspells names of Shona politicians such as Kasukuwere, Mnangagwa and Chiyangwa. His name identifies him as a proud Ndebele speaker from Nkayi, a region where 'ideally' no one speaks Shona, which explains why he cannot spell Shona names correctly. Spelling names of corrupt Shona politicians correctly would figuratively corrupt him too.

Unlike the previous readers who are concerned about other corrupt politicians apart from Moyo, Bro Themba, a reader of the NewZimbabwe.com story, is interested in establishing whether Moyo is guilty or not:

Moyo has publicly confesed that he took money from Zimdef and donated it to Zanu Pf... What is wrong with aresting him?

${ }^{3}$ Robert Mugabe criticized Jonathan Moyo in the aftermath of the Tsholotsho declaration in which Moyo was accused of having conspired to oust Mugabe. He was later dismissed from the party. 
What is interesting about this comment is the language of charity that the reader uses to refer to how Moyo diverted Zimdef funds to ZANU PF political activities. His argument is that Moyo is guilty because he donated money which did not belong to him.

The story 'Jonathan Moyo in corruption storm' (Mambo 2016), published by The Independent (7 October 2016) also received a number of comments. Zvichapera interpreted the scandal through what Semetko and Valkenburg (2000) would call a conflict frame. The name 'Zvichapera' literally means 'it will come to an end' which is probably a prophetic gesture to the demise of Mugabe's rule. Zvichapera's advice that ZACC officials should keep this evidence under lock and key - Mugabe will not be in power forever', shows that he has lost faith in Zimbabwe's justice system. His hope is in the post-Mugabe future that he believes will bring justice to those corrupt politicians who enjoyed immunity under the Mugabe regime. Commenting on the same story, another reader, Dewa, frames corruption as a survival mechanism for the ruling party where 'officials procure funds for the party' through corruption. Dewa sees corruption as a funding mechanism for ZANUPF political activities.

In response to the story 'Prof Moyo sues over Zimdef' (Share 2016) published by The Herald (2 November 2016), a reader by the name Judas Iscariot defended Moyo on the basis that he is not the only corrupt official in ZANU-PF. The name 'Judas Iscariot' is reminiscent of the biblical Judas, one of Jesus' twelve disciples who later betrayed him. The biblical allusion to 'those with logs in their own eyes' probably refers to ZACC officials and all those who accused Moyo of corruption. In The Herald story, Moyo threatened to sue all those who had allegedly planned to bring him down, not because he had evidence to prove his innocence, but because he knew that they also had 'logs in their own eyes'. Judas Iscariot believes that Moyo is 'untouchable' because he has information on the corrupt activities of his accusers.

Another reader named 'Progressive Zimbabwean', interpreted the scandal from a moral perspective. The fact that Moyo, a corrupt politician, would go on to sit 'next to the President whilst our children are being capped' is repulsive to him. This image of a President who caps graduates while sitting next to a corrupt Cabinet Minister exemplifies an irredeemably corrupt society that reproduces unethical behaviour. For this reader, Zimbabwean politicians do not model exemplary behaviour. Therefore, they are toxic to society's moral fabric. As the Chancellor of all universities in Zimbabwe, Mugabe would cap 
graduating students at Universities and colleges. Progressive Zimbabwean is worried about the kind of values that politicians impart to society.

In response to the story 'Jonathan Moyo docket ready' (Chidza 2016), Mamelodi poetically laments what he perceives as moral degeneration in Zimbabwean politics:

\section{Primitive nation. \\ Professors of theft and slander \\ His Excellency of cheating and murder \\ I swear to uphold the constitution.... (what?)... you? \\ Doctorates of deception bought for cash in Mafia dungeons.}

In this poetic comment, Mamelodi laments the desecration of moral values by Zimbabwe's political elite. Jonathan Moyo, a professor that society expects to embody values of excellence and honesty, has become an epitome of 'theft and slander' while the President who is expected to uphold the constitution has become a paragon of corruption. In the early years of his rule, Mugabe postured as an educated and refined politician, However, in his latter days, Zimbabweans had lost respect for him because of his dictatorial tendencies. Mbembe (2001) has described relations in the post colony as governed by what he calls 'the logic of conviviality' where the ruled and the rulers exist together in a banal but harmonious relationship. The selected newspapers generally projected Jonathan Moyo as an immoral, unethical and corrupt politician but readers seem to have different views that contradict the agendas of the media.

\section{Implications for Future Research}

New media technologies have radically transformed the interface between citizens and traditional sources of news such as newspapers, radio and television. With the advent of new media technologies, citizens do not only have power to contest news frames and agendas of mainstream media but also to frame their own news and set their own agendas. Future studies should pursue this burgeoning field of study by analysing how, in specific instances, ordinary citizens create their own news rather than follow the agendas of established media houses. While this study focused on online discussion forums as platforms for citizen engagement, future studies can focus on similar 
platforms such as WhatsApp, Facebook and Twitter as platforms of civic engagement and critical citizenship. Future research may also investigate specific stories on social media that contest narratives pedalled by established media channels especially in relation to individuals or groups that mainstream media portrays in a negative light. It might also be worthwhile for future studies to use these platforms as an avenue to study public democratic participation in the online space and the extent to which online platforms give a voice to, and empower, marginalised citizens.

\section{Conclusion}

This article analysed popular responses to the Zimdef corruption scandal as portrayed by selected newspapers. It argued that ordinary Zimbabweans refused to consume news frames and agendas promoted by media organisations. Far from embracing media frames, newsreaders developed their own frames and set their own agendas. Most newspapers framed Jonathan Moyo as a morally bankrupt and common criminal who deserved prosecution and incarceration. However, readers dismissed the narrow frames provided by newspapers arguing that it does not make sense to prosecute Moyo because he was simply a symptom of a much more serious and deeper political crisis within ZANU-PF. Other readers, particularly those from Matebeleland, felt that their region had suffered marginalisation since independence and hence Moyo's corruption was a bad deed with good intentions. Instead of focusing on Moyo and portraying him as the rotten apple of Zimbabwean politics, readers framed corruption as a much broader societal problem that warranted a complete overhaul of the existing political system. Newsreaders' comments analysed in this article show that ordinary Zimbabweans do not depend on mainstream media frames and agendas but rather formulate their own frames and set their own agendas. Ordinary citizens opposed negative representations of Jonathan Moyo in Zimbabwean newspapers by firstly arguing that Moyo was one among many corrupt politicians and secondly that his 'corrupt behaviour' addressed real problems such as the marginalisation of Matebeleland. For some readers, corruption is not always an evil practice but an economic strategy that can address the unequal distribution of national resources. This article has thus demonstrated that ordinary citizens are not mere consumers of information but also active producers and contributors to public discourse. 


\section{References and Bibliography}

Anon. 2016b. Jonathan Moyo's Many Corruption Faces. NewZimbabwe.com 12 October. Available at: http://www.newzimbabwe.com/news-31690Jonathan+Moyo\%E2\%80\%99s+many+corruption+faces/news.aspx (Accessed on 15 November 2017.)

Anon. 2016c. Prof Moyo in '270k Corruption' Storm. The Chronicle 8 October. Available at: http://www.chronicle.co.zw/prof-moyo-in-270kcorruption-storm/ (Accessed on 15 November 2017.)

Ardèvol-Abreu, A. 2015. Framing Theory in Communication Research in Spain: Origins, Development and Current Situation. Revista Latina de Comunicación Social 70: 423 - 450. https://doi.org/10.4185/RLCS$1053 \mathrm{en}$

Aruguete, N. 2017. The Agenda-setting Hypothesis in the New Media Environment. Comunicacion y Sociedad 28, 28: 35-58. https://doi.org/10.32870/cys.v0i28.2929

Bode, L., B. Sayre, C. Shah, D. Shah \& D. Wilcox 2010. Agenda Setting in a Digital Age: Tracking Attention to California Proposition 8 in Social Media, Online News, and Conventional News. Policy \& Internet 2, 2: 7 -

32. https://doi.org/10.2202/1944-2866.1040

Borah, P. 2011. Conceptual Issues in Framing Theory: A Systematic Examination of a Decade's Literature. Journal of Communication 61: 246 - 263. https://doi.org/10.1111/j.1460-2466.2011.01539.x

Cacciatore, M.A., D.A. Scheufele \& S. Iyengar 2016. The End of Framing as we Know it ... and the Future of Media Effects. Mass Communication and Society 19, $1: 7$ - 23. https://doi.org/10.1080/15205436.2015.1068811 Chidza, R. 2016a. Jonathan Moyo Docket Ready. NewsDay 14 October. Available at: https://www.newsday.co.zw/2016/10/14/zimdef-gatemandiwanziras-company-speaks/ (Accessed on 20 November 2017.)

Entman, R.B. 1993. Framing: Toward Clarification of a Fractured Paradigm. Journal of Communication 43, 4: 51 - 58. https://doi.org/10.1111/j.14602466.1993.tb01304.x

Gamson, W.A. 1996. Media Discourse as a Framing Resource. In Crigler, A.N. (ed.): The Psychology of Political Communication. Ann Arbor: University of Michigan Press. https://doi.org/10.1086/229213

Gamson, W.A. \& A. Modigliani 1989. Media Discourse and Public Opinion on Nuclear Power: A Constructionist Approach. American Journal of Sociology 95, 1: 1 - 37. 
Goffman, E. 1974. Frame Analysis: An Essay on the Organization of Experience. Cambridge, MA: Harvard University Press.

Hamdy, N. \& E.H. Gomaa 2012. Framing the Egyptian Uprising in Arabic Language Newspapers and Social Media. Journal of Communication 62: 195 - 211. https://doi.org/10.1111/j.1460-2466.2012.01637.x

Idid, S. \& S. Elawad 2015. Setting the Media Agenda: A Study of the 2010 Sudanese Presidential Elections. Intellectual Discourse 23, 1: 53 - 74. Available at:

http://journals.iium.edu.my/intdiscourse/index.php/islam/article/view/65 9. (Accessed on 9 May 2019.)

Kinder, D.R. \& L.M. Sanders 1990. Mimicking Political Debate with Survey Questions: The Case of White Opinion on Affirmative Action for Blacks. Social Cognition 8, 1: 73 - 103. https://doi.org/10.1521/soco.1990.8.1.73 Mambo, E. 2016. Jonathan Moyo in Corruption Storm. Zimbabwe Independent 7 October. Available at:

https://www.theindependent.co.zw/2016/10/07/jonathan-moyocorruption-storm/ (Accessed on 22 November 2017).

Makombe, R. 2018. Framing Corruption Narratives in Zimbabwe: A Critical Review of the Zimdef Corruption Scandal as Portrayed in Zimbabwean Newspapers. JAMS 10, 1: 73 - 85.

https://doi.org/10.1386/jams.10.1.73_1

Mbembe, A. 2001. On the Postcolony. Berkeley: University of California.

McCombs, M. 2014. Setting the Agenda. The Mass Media and Public Opinion. Cambridge: Polity Press.

Meraz, S. 2011. The Fight for 'how to think': Traditional Media, Social Networks, and Issue Interpretation. Journalism 12, 1: 107 - 127. https://doi.org/10.1177/1464884910385193

Moy, P., D. Tewksbury \& E.M. Rinke 2016. Agenda-setting, Priming, and

Framing. In Jensen, K.B. \& R.T. Craig (eds.): The International Encyclopedia of Communication Theory and Philosophy 1: 52 - 64.

https://doi.org/10.1002/9781118766804.wbiect266

Ncube, X. 2016. Prof Moyo Case Shocking Details. The Standard 9 October.

Available at: https://www.thestandard.co.zw/2016/10/09/prof-moyocase-shocking-details/

(Accessed on 22 November 2017.)

Park, S., K.J. Holody \& X. Zhang 2012. Race in Media Coverage of School Shootings: A Parallel Application of Framing Theory and Attribute 
Agenda Setting. Journalism \& Mass Communication Quarterly 89, 3: 475 - 494. https://doi.org/10.1177/1077699012448873

Semetko, H. \& P. Valkenburg 2000. Framing European Politics: A Content Analysis of Press and Television News. Journal of Communication 50, 2: 93 - 109. https://doi.org/10.1111/j.1460-2466.2000.tb02843.x

Share, F. 2016. Prof Moyo Sues over Zimdef, The Herald 2 November. Available at: http://www.herald.co.zw/prof-moyo-threatens-lawsuits/ (Accessed on 22 November 2017).

Rodwell Makombe Department of English Literary and Cultural Studies University of the Free State South Africa MakombeR@ufs.ac.za

Mpitseng Tladi Masters student Department of English and Cultural Studies University of the Free State, Qwaqwa Campus South Africa mpitseng001@gmail.com 